\title{
PENGELOLAAN TENAGA PENDIDIK PADA SEKOLAH DASAR
}

\section{THE MANAGEMENT OF TEACHERS AT ELEMENTARY SCHOOLS}

\author{
RR Aliyyah'1a, SA Lutfah', dan ZK Lathifah² \\ ${ }^{1}$ Program Studi Pendidikan Guru Sekolah Dasar, Fakultas Keguruan dan Ilmu Pendidikan, \\ Universitas Djuanda Bogor, Jl. Tol Ciawi No. 1 Kotak Pos 35 Ciawi Bogor 16720 \\ 2 Program Studi Manajemen Pendidikan Islam, Fakultas Keguruan dan Ilmu Pendidikan, \\ Universitas Djuanda Bogor, Jl Tol Ciawi No. 1 Kotak Pos 35 Ciawi Bogor 16720 \\ a Korespondensi: Rusi Rusmiati Aliyyah, Email: rusi.rusmiati@unida.ac.id \\ (Diterima: 17-06-2017; Ditelaah: 18-06-2017; Disetujui: 12-08-2017)
}

\begin{abstract}
This study is intended to find, describe and provide information about the management of educators in SD Pertiwi Kota Bogor. This research uses a qualitative approach with a case study method. Data was collected through technical observations, interviews and documentation. Data analysis techniques that researchers used with data deduction, data presentation, and conclusion. The result of this research is the procedure of recruitment activity at SD Pertiwi Kota Bogor which has a difference with other schools. These differences are in the application selection phase, written and non-written test, and orientation. In addition, SD Pertiwi Kota Bogor has a leading career development program in the form of scholarship fund for Undergraduate School (S1) - Postgraduate School (S2) as well as training and coaching programs that are implemented continuously or continuously in one week according to the schedule.
\end{abstract}

Keywords: career development, management of educators, recruitment.

\begin{abstract}
ABSTRAK
Penelitian ini bertujuan untuk mengetahui, mendeskripsikan dan memberikan informasi mengenai pengelolaan tenaga pendidik di SD Pertiwi Kota Bogor. Penelitian ini menggunakan pendekatan kualitatif dengan metode studi kasus. Data dikumpulkan melalui teknik observasi, wawancara dan dokumentasi. Teknik analisis data yang digunakan ialah dengan reduksi data, penyajian data, dan penarikan kesimpulan. Hasil dari penelitian ini adalah prosedur kegiatan rekrutmen di SD Pertiwi Kota Bogor yang memiliki perbedaan dengan sekolah lainnya. Perbedaan tersebut diantaranya ialah pada tahap seleksi lamaran, tes tertulis dan non-tertulis, dan orientasi. Selain itu juga SD Pertiwi Kota Bogor memiliki program pengembangan karier unggulan berupa dana beasiswa pendidikan tingkat lanjut sarjana (S1)-pascasarjana (S2) dan juga program pelatihan dan pembinaan yang dilaksanakan secara berkelanjutan atau berkelanjutan dalam satu minggu sekali sesuai dengan jadwal yang telah ditetapkan.
\end{abstract}

Kata kunci: pengelolaan tenaga pendidik, pengembangan karier, rekrutmen.

Aliyyah RR, SA Lutfah, dan ZK Lathifah. 2017. Pengelolaan tenaga pendidik pada sekolah dasar. Didaktika Tauhidi Jurnal Pendidikan Guru Sekolah Dasar 4(2): 75-86. 


\section{PENDAHULUAN}

Sekolah sebagai salah satu lembaga pendidikan yang di dalamnya terdapat kepala sekolah, guru-guru, pegawai tata usaha, dan murid-murid memerlukan adanya pengelolaan organisasi/tenaga pendidik yang baik supaya dapat berjalan dengan lancar sesuai arah dan tujuannya. Pengelolaan tenaga pendidik yang baik, dimaksudkan agar pembagian tugas dan tanggung jawab dapat merata kepada semua orang sesuai dengan kecakapan dan fungsinya masing-masing. Tiap orang mengerti dan menyadari tugasnya dan tempatnya di dalam struktur organisasi itu. Dengan demikian dapat dihindari pula adanya tindakan yang sewenang-wenang atau otoriter dari kepala sekolah, dan sebaliknya dapat diciptakan adanya suasana yang demokratis dalam menjalankan roda sekolah.

Manajemen SDM dalam dunia pendidikan adalah proses menangani berbagai masalah pada ruang lingkup siswa, karyawan, pegawai, buruh, manajer, dan tenaga kerja lainnya dalam bidang pendidikan untuk menunjang aktivitas bidang pendidikan demi mencapai tujuan yang telah ditentukan. Manajemen sumber daya manusia adalah konteks pendidikan yang dapat dikelompokkan menjadi sumber daya manusia tenaga pendidik dan kependidikan atau guru dan tenaga administrasi, dan sumber daya manusia atau peserta didik.

Tenaga atau personalia pendidikan adalah semua orang yang terlibat dalam tugas-tugas pendidikan, yaitu para guru/dosen sebagai pemegang peran utama, manajer/administrator, para supervisor, dan para pegawai. Para personalia pendidikan perlu dibina agar bekerja sama secara lebih baik dengan masyarakat. Menurut Undang-Undang Sistem
Pendidikan Nasional Nomor 20 Tahun 2003, tenaga kependidikan itu adalah anggota masyarakat yang mengabdikan diri dan diangkat untuk menunjang penyelenggaraan pendidikan. Sedangkan pendidik adalah tenaga kependidikan yang berkualitifikasi sebagai guru, dosen, konselor, widyaiswara, tutor, instruktur, fasilitator, dan sebutan lain yang sesuai dengan kekhususannya, serta berpartisipasi dalam menyelenggarakan pendidikan. Untuk dapat menghasilkan output yang berkualitas maka suatu lembaga pendidikan dapat menempuh prosedur awal yaitu melalui perencanaan SDM yang matang pada saat perekrutan.

Dengan demikian, sistem pendidikan di sekolah tersebut menjadi lebih baik dan akan mencapai suatu keberhasilan. Selain pada tahap perekrutan, tahap pengembangan karier guru pun sangat penting untuk diperhatikan. Karena pada tahap pengembangan karier guru akan berdampak pada kinerja guru. Selaras dengan hasil dari LAKIP Kemendikbud tahun 2015 mengenai kinerja guru mengatakan bahwa ketercapaian sasaran strategis meningkatnya profesionalisme dan distribusi guru dan tenaga kependidikan didukung melalui ketercapaian lima indikator kinerja, yaitu: 1) Presentase guru, pendidik lainnya, dan tenaga kependidikan profesional; 2) Jumlah PTK PAUD profesional; 3) Jumlah PTK Dikmas profesional; 4) Presentase satuan pendidikan dasar memiliki jumlah guru sesuai SPM; 5) Presentase satuan pendidikan menengah memiliki jumlah guru sesuai SNP. Tingkat ketercapaian indikator kinerja yang digunakan untuk mengukur sasaran strategis meningkatnya profesionalisme dan distribusi guru serta tenaga kependidikan dijabarkan seperti pada Tabel 1. 
Tabel 1 Persentase profesionalitas tenaga pendidik dan kependidikan

\begin{tabular}{|c|c|c|c|c|}
\hline \multirow[b]{2}{*}{ Sasaran Setrategis } & \multirow[b]{2}{*}{ Indikator Kinerja } & \multicolumn{3}{|c|}{ Tahun 2015} \\
\hline & & $\begin{array}{c}\text { Target } \\
(\%)\end{array}$ & $\begin{array}{c}\text { Realisasi } \\
\quad(\%)\end{array}$ & $\begin{array}{c}\text { Peningkatan } \\
(\%)\end{array}$ \\
\hline \multirow[t]{5}{*}{$\begin{array}{l}\text { Meningkatnya } \\
\text { profesionalisme dan } \\
\text { distribusi guru dan tenaga } \\
\text { kependidikan }\end{array}$} & $\begin{array}{l}\text { Persentase guru, } \\
\text { pendidik lainnya, dan } \\
\text { tenaga kependidikan } \\
\text { profesional }\end{array}$ & 45 & 84,02 & 187 \\
\hline & $\begin{array}{l}\text { Jumlah PTK PAUD } \\
\text { profesional }\end{array}$ & 16 & 51,24 & 320 \\
\hline & $\begin{array}{l}\text { Jumlah PTK Dikmas } \\
\text { profesional }\end{array}$ & 3 & 56,07 & 1.869 \\
\hline & $\begin{array}{lr}\text { Persentase } & \text { satuan } \\
\text { pendidikan } & \text { dasar } \\
\text { memiliki jumlah guru } \\
\text { sesuai SPM }\end{array}$ & 68,01 & 46,51 & 73,24 \\
\hline & $\begin{array}{l}\text { Persentase satuan } \\
\text { pendidikan menengah } \\
\text { memiliki jumlah guru } \\
\text { sesuai SNP }\end{array}$ & 63,50 & 46,51 & 73,24 \\
\hline
\end{tabular}

Capaian kinerjanya telah melampaui target yang ditetapkan, meskipun dalam pelaksanaannya belum sepenuhnya optimal. Pada tahun 2015, persentase guru, tenaga pendidik lainnya dan tenaga kependidikan profesional ditargetkan mencapai $45 \%$. Dan pada tahun tersebut jumlah guru, tenaga pendidik lainnya, dan tenaga kependidikan yang profesional telah mencapai angka 84.02\%. Dengan persentase capaian indikator kinerja ini sebesar 187\%. Sebagai tenaga profesional, guru diharapkan dapat berfungsi untuk meningkatkan martabat dan peran guru sebagai agen pembelajaran dan berfungsi untuk meningkatkan mutu pendidikan nasional. Oleh sebab itu, agar dapat mencapai pelaksanaan yang optimal maka sudah seyogyanya setiap lembaga pendidikan memanfaatkan SDM sebagai pemegang peran utama aktivitas pendidikan dengan melewati berbagai perencanaan tersebut dengan baik. Karena dengan segala perencanaan yang sudah sesuai dengan prosedur diharapkan dapat menjadikan sekolah tersebut meraih keberhasilan yang akan menjadikan sekolah dengan titel terbaik yang nantinya dapat bersaing dengan dunia global.

Upaya untuk mendapatkan sebuah penghargaan dan predikat sekolah unggul atau sekolah terbaik bukanlah hal yang mudah. Untuk mencapai tujuan tersebut dibutuhkan usaha, kesiapan dan juga rencana yang matang dimulai dari sistem, pengelolaan, manajemen, bahan ajar, bahkan kualitas serta kompetensi yang dimiliki oleh SDM. Usaha-usaha tersebut sangatlah menunjang suatu lembaga pendidikan untuk mendapatkan penghargaan tersebut. Sekolah dengan titel unggul dan terbaik bukan semata-mata hanya untuk eksistensi saja, karena pada 
kenyataannya titel tersebut akan memiliki tanggung jawab yang harus dilaksanakan sebagaimana mestinya. Seperti, sekolah harus mempertahankan bahkan meningkatkan kualitas dan mutu pendidikannya dari segi efektivitas pembelajaran, kurikulum, strategi dan lainlain. Persiapan atau perencanaan merupakan langkah awal ketika kita akan memulai sesuatu. Tak terkecuali dengan pembahasan pada kali ini. Telah kita singgung sebelumnya, salah satu penunjang yang harus dilakukan untuk mendapatkan penghargaan atau predikat sekolah terbaik ialah kualitas serta kompetensi yang dimiliki oleh SDM (Sumber Daya Manusia). Dalam konsep manajemen SDM, manajemen SDM merupakan bagian dari ilmu manajemen yang memfokuskan perhatiannya pada pengaturan peranan SDM dalam kegiatan suatu organisasi. Manajemen SDM menganggap bahwa karyawan adalah kekayaan (aset) utama organisasi yang harus dikelola dengan baik. Jadi SDM bersifat lebih strategis bagi organisasi dalam mencapai tujuan yang telah ditetapkan.

SD Pertiwi merupakan salah satu sekolah dasar swasta yang maju prestasinya dalam bidang akademik maupun non-akademik. Keberhasilan yang diraih oleh SD pertiwi didapatkan karena prestasi dan mutu pendidikan yang baik sehingga dapat menjadikan sekolahnya menjadi nomor satu di Bogor Timur. Untuk mencapai keberhasilan dan meningkatkan mutu pendidikan, sekolah membutuhkan SDM yang berkompeten dan memiliki keahlian khusus dibidangnya masing-masing. Meningkatkan mutu pendidikan dari SD tersebut salah satunya karena baiknya kualitas SDM yang ada di dalamnya. Untuk mendapatkan SDM yang berkualitas diperlukan rekrutmen yang baik. Maka dari itu, untuk mengetahui bagaimana proses rekrutmen tersebut dilakukan. Rekrutmen merupakan proses mencari, menemukan, dan menarik pelamar untuk dipekerjakan dalam suatu organisasi. Proses rekrutmen sumber daya manusia tidak boleh diabaikan. Hal ini disebabkan untuk menjaga supaya tidak terjadi ketidaksesuaian antara apa yang diinginkan dan apa yang dicapai. Artinya, organisasi tersebut tidak akan memperoleh karyawan yang tepat, dalam arti baik kualitas maupun kuantitasnya. Apabila tidak terjadi kesesuaian yang diharapkan oleh organisasi tersebut dapat dikatakan kemungkinan aktivitas kerja kurang efektif dan efisien, maka organisasi tersebut akan mengalami kegagalan (Sutrisno 2014).

\section{MATERI DAN METODE}

\section{Materi}

\section{Tenaga Pendidik}

Tenaga atau personalia pendidik adalah orang yang terlibat dalam tugas tugas pendidikan, yaitu para guru/dosen sebagai pemegang peran utama, manajer/administrator, para supervisior, dan para pegawai. Para personalia pendidikan perlu dibina agar bekerja sama secara lebih baik dengan masyarakat (Heryati dan Muhsin 2014). Tenaga pendidik adalah gurupada TK/RA, SD/MI, SMP/MTs, SMA/MA, SDLB/SMALB, SMK/MAK, satuan pendidikan Paket A, Paket B dan Paket C, dan pendidik pada lembaga khusus dan pelatihan. Guru adalah seorang profesional dan bukan hanya sekedar sebagai seorang pahlawan tanpa tanda jasa yang tidak memperdulikan aspek ekonomis dari profesinya tersebut. Tenaga pendidik adalah anggota masyarakat yang 
bertugas membimbing, mengajar, dan atau melatih peserta didik (Prihatin 2011).

Kegiatan untuk mendapatkan tenaga pendidik dan kependidikan yang berkualitas dan memenuhi prinsip the right man on the right place maka dilakukan kegiatan perekrutan yang diawali dengan kegiatan seleksi, dilanjutkan dengan kegiatan orientasi dan penempatan. Sebelum dilaksanakan seleksi, terlebih dahulu ditetapkan kualifikasi dan kompetensi yang dibutuhkan untuk menduduki jabatan tertentu. Pada umumnya kualifikasi meliputi: keahlian, pengalaman, umur, jenis kelamin, pendidikan, keadaan fisik dan lainnya. Kompetensi adalah kemampuan yang harus dimiliki oleh seseorang dalam melaksanakan tugas tertentu. Kompetensi merupakan perwujudan pengetahuan, sikap dan keterampilan yang terinternalisasi dalam setiap gerak langkahnya. Mengenai kualifikasi dan kompetensi tenaga pendidik/guru (Rugayah 2010).

\section{Rekrutmen}

Rekrutmen atau "Recruting" adalah kegiatan analisis jabatan atau analisis pekerjaan yang berisikan uraian pekerjaan. Uraian pekerjaan menjelaskan tentang rincian tugas serta tanggung jawab, juga kondisi perekrutan pekerjaan (Harsono 2011). Rekrutmen (Recruitment) adalah serangkaian aktivitas mencari dan memikat pelamar kerja dengan motivasi, kemampuan, keahlian, dan pengetahuan yang diperlukan guna menutupi kekurangan yang diidentifikasi dalam perencanaan kepegawaian (Setiani 2013). Berdasarkan pendapat para pakar tersebut, maka rekrutmen merupakan proses pencarian tenaga kerja yang memiliki kemampuan serta keahlian untuk menjadi pegawai yang dilakukan secara terencana agar memenuhi syarat-syarat guna memperoleh jabatan tertentu suatu organisasi.

Tahap pertama dari proses rekrutmen ialah seleksi, selanjutnya tes dan yang terakhir adalah orientasi. Seleksi sumber daya manusia merupakan suatu proses yang memerlukan penilaian dan perkiraan untuk memprediksi secara tepat khususnya dalam menentukan tingkat investasi, kualitas yang baik, spekulatif, atau resiko tinggi. Beberapa keuntungan yang diperoleh dari pelaksanaan sistem seleksi tradisional adalah efektivitas biaya, penurunan tingkat pemborosan dana dan waktu pengawasan, dan minimalisasi masalah penempatan kerja. (Tim Dosen Administrasi PendidikanUniversita Pendidikan Indonesia 2012).

Tes adalah suatu alat atau prosedur yang sistematis dan objektif untuk memperoleh data-data atau kategori-kategori yang diinginkan tentang seseorang dengan cara yang boleh dikatakan tepat dan cepat (Sukinah 2016). Tes (test) merupakan suatu alat penilaian dalam bentuk tulisan untuk mencatat atau mengamati prestasi siswa yang sejalan dengan target penilaian (Kuncoro 2017). Tes adalah sebagai suatu pertanyaan atau tugas atau seperangkat tugas yang direncanakan untuk memproleh informasi tentang atribut pendidikan atau psikologik tertentu dan setiap butir pertanyaan atau tugas tersebut mempunyai jawaban atau ketentuan tersebut, maka jawaban anda dianggap salah. Berdasarkan hal tersebut, maka tes merupakan suatu alat pengukuran yang direncanakan untuk memperoleh informasi yang diinginkan dengan cara yang tepat.

Orientasi adalah kegiatan yang dilakukan untuk memperkenalkan kepada pegawai baru terhadap lingkungan kerja, tugas-tugas dan personal yang ada di lingkungannya. Orientasi adalah salah satu teknik yang 
sangat lumrah digunakan untuk mencoba mengurangi jumlah pegawai baru yang berhenti, dengan menyelenggarakan program pengenalan (Siagian 2008). Dengan demikian, orientasi merupakan kegiatan yang dilakukan untuk memperkenalkan karyawan atau pegawai baru terhadap lingkungannya.

Pengembangan karier adalah kegiatan pengembangan personel agar dapat memenuhi rencana karier yang dipilih. Pengembangan karier adalah peningkatanpeningkatan pribadi yang dilakukan untuk mencapai suatu rencana karier (Sutrisno 2009). Pembinaan atau pengembangan karier tenaga kependidikan merupakan usaha mendayagunakan, memajukan, dan meningkatkan produktivitas kerja setiap tenaga kependidikan yang ada di seluruh tingkatan manajemen organisasi dan jenjang pendidikan (Mustari 2014). Berdasarkan para pakar tersebut, maka pengembangan karier adalah suatu kegiatan pengembangan individu untuk mencapai suatu rencana karier untuk meningkatkan dan memajukan produktivitas setiap tenaga kerja maupun tenaga kependidikan.

\section{Metode}

Tujuan penelitian adalah untuk mengetahui, mendeskripsikan, dan memberikan infromasi mengenai rekrutmen dan pengembangan karier tenaga pendidik dan kependidikan di SD Pertiwi Kota Bogor. Waktu penelitian dilaksanakan pada bulan Januari s/d Maret 2017.

Metode penelitian adalah metode penelitian yang digunakan untuk meneliti pada kondisi obyek yang alamiah, dimana peneliti adalah sebagai instrumen kunci, teknik pengumpulan data dilakukan secara triangulasi, analisis data bersifat induktif, dan hasil penelitian kualitatif lebih menekankan makna dari pada generalisasi.
(Sugiono 2014). Penelitian kualitatif adalah penelitian yang menghasilkan prosedur analisis yang tidak menggunakan prosedur analisis statistik atau cara kuantifikasi lainnya. Jelas bahwa pengertian ini mempertentangkan penelitian kualitatif dengan penelitian yang bernuansa kuantitatif yaitu dengan menonjolkan bahwa usaha kuantifikasi apapun tidak perlu digunakan pada penelitian kualitatif (Moleong 2007).

Data penelitian ini menggunakan multisumber bukti/data sebagaimana disampaikan oleh Yin (2004), bahwa untuk keperluan studi kasus bisa berasal dari enam sumber, yaitu dokumen, rekaman arsip, wawancara, pengamatan langsung, observasi partisipan, dan perangkatperangkat fisik. Sumber data penelitian diperoleh dari sumber data primer dan sumber data sekunder. Sumber data primer adalah sumber data yang langsung diberikan data kepada pengumpul data. Data primer dalam penelitian diperoleh langsung oleh kepala sekolah, guru-guru, serta pihak yang dianggap memiliki kepentingan pada situasi sosial obyek yang akan diteliti. Sedangkan sumber data sekunder adalah sumber yang tidak langsung memberikan data kepada pengumpul data. Data sekunder yang dimaksudkan adalah data arsip, serta dokumen-dokumen tentang beberapa hal yang terkait dengan kegiatan pendidikan di SD Pertiwi.

Teknik pengumpulan data yang digunakan dalam penelitian ini adalah observasi, wawancara, dan dokumentasi. Prosedur analisis data menggunakan model analisis Miles and Huberman, yakni terdiri dari tiga alur kegiatan yang terjadi secara bersamaan yaitu reduksi data, penyajian data, dan penarikan kesimpulan atau verifikasi (Miles dan Huberman 1992). 
Sedangkan keabsahan (trustworthiness) digunakan melalui drajat kepercayaan (credibility), keterahlian (transferability), kebergantungan dependability (realibilitas), dan kepastian (confirmability).

\section{HASIL DAN PEMBAHASAN}

Rekrutmen tenaga pendidik dilakukan melalui observasi awal tentang kualitas guru SD Pertiwi yang harus sesuai dengan standar kompetensi guru. Proses Rekrutmen di SD Pertiwi memiliki 3 Prosedur tetap, yaitu seleksi, tes dan orientasi. Dengan melalui tahap/prosedur awal pada saat proses rekrutmen tenaga pendidik berupa seleksi lamaran, kemudian tes tertulis, dan non-tertulis. Tes tertulis diantarnya, dapat mengerjakan administrasi pembelajaran yang baik berupa RPP dan mengajar (microteaching). Tes kedua yang dilakukan adalah tes wawancara, dan selanjutnya adalah melakukan orientasi. Tahap orientasi bertujuan untuk penilaian dan menentukan hasil akhir dari rangkaian atau proses rekrutmen. Selain itu, kegiatan orientasi bertujuan untuk memperkenalkan tentang kehidupan, sosial budaya, lingkungan kerja disekitar tempat kerja dan Memberitahukan menganai tujuan, riwayat, filosofi, prosedur, dan peraturan di suatu organisasi.

Ditemukan suatu hal yang berbeda pada proses rekrutmen di SD Pertiwi. Dimana pada tahap orientasi yang dilakukan oleh calon pendidik yang hendak menjadi guru di SD Pertiwi digunakan suatu metode yang berbeda dengan sekolah-sekolah yang lainnya. Dimana proses orientasi dilakukan dalam jangka waktu yang pendek dan panjang untuk menentukan bahwa calon pendidik tersebut layak untuk menjadi seorang tenaga pendidik tetap di SD Pertiwi. Tahap pertama dalam orientasi itu berangsung selama 3 bulan lalu tahap selanjutnya berlangsung selama 2 tahun. Tahap pertama calon pendidik masih berstatus GTT (Guru Tidak Tetap) lalu untuk tahap kedua ialah GTY (Guru Tetap Yayasan). Untuk dapat menjadi GTY, calon pendidik harus bisa melewati tahap orientasi pertama tersebut selama 3 Bulan. Sehingga guru tersebut bisa masuk ketahap GTY. Kegiatan orientasi yang dilakukan di SD Pertiwi bisa disebut Induksi atau mentoring. Dimana pada saat calon pendidik sudah dikatakan layak untuk menjadi guru di SD Pertiwi, maka guru tersebut ada dalam tanggung jawab salah satu mentor atau pembimbing yang akan membimbing selama 3 bulan lamanya.

Kegiatan orientasi dilakukan oleh setiap calon pendidik yang telah lolos menjadi guru dan mengisi kekosongan jabatan. Guru baru tersebut tidak terlepas dari supervisi (pengawas). Pengawasan tersebut biasa dilakukan oleh kepala sekolah, wakil kepala sekolah, maupun guru pamong. Pembimbing biasanya dipilih oleh kepala sekolah untuk membimbing guru baru dalam menyesuaikan atau memperkenalkan sistem maupun lingkungan di sekolah. Pembimbing diambil dari salah satu guru yang memiliki profesionalitas dan juga masa jabatan lama. Biasanya guru pembimbing itu diambil dari masing-masing tingkatan kelas dan ditugaskan untuk membimbing guru baru tersebut agar dapat beradaptasi dan memahami lingkungan barunya. Lalu untuk supervisi selalu dilakukan secara random. Jadi pada saat guru baru mengajar, tiba-tiba para pengawas seperti kepala sekolah atau pun wakil kepala sekolah masuk ke dalam kelas untuk melihat progress guru baru dalam mengajar dan melakukan penilaian. Hasil penilaian tersebut akan dimasukan dalam surat penawaran kerja atau surat rekomendasi dan juga perjanjian kerja 
dengan calon yang bersangkutan kepada yayasan yang menaungi SD Pertiwi. Dengan diberlakukannya kegiatan orientasi tersebut maka dapat memudahkan guru baru dalam menjalankan aktivitas mengajarnya dan juga sekolah bisa mendapatkan guru baru yang sudah memenuhi standar mengajar di sekolah.

Agar dapat memperoleh tenaga pendidik yang berkualitas dan memenuhi jumlah yang sesuai dengan kebutuhan maka dibutuhkan suatu panitia khusus dan metode khusus dalam kegiatan rekrutmen. Dengan dibuatnya tim kepanitiaan dalam kegiatan rekrutmen maka semakin kecil kemungkinan untuk terjadi ketidaksesuaian antara apa yang diinginkan dan apa yang didapat. Dan sekolah tidak mendapatkan guru yang tidak tepat dalam arti baik dari kualitas maupun kuantitasnya. Karena apabila tidak terjadi kesesuaian yang diharapkan maka dapat dikatakan kemungkinan aktivitas kerja akan menjadi kurang efektif dan efisien.

Kegiatan rekrutmen dilakukan secara kondisional tanpa tanggal tertentu. Tidak ditetapkannya jadwal atau tanggal khusus untuk melakukan kegiatan rekrutmen, bukan menjadi masalah besar di SD Pertiwi. Karena hal tersebut memang sudah dilakukan dari tahun ke tahun. Tujuan dengan tidak ditetapkannya jadwal khusus maka SD akan fokus terhadap apa yang akan dilakukan bila terjadi kekosongan pegawai saja. Bila ditetapkan jadwal atau waktu untuk selalu membuka kegiatan rekrutmen maka harus banyak pertimbangan dengan tenaga pendidik yang memang sudah lama masa kerjanya di SD Pertiwi. Dengan banyaknya jumlah calon pelamar yang mengirimkan lamaran pada saat ada kekosongan jabatan, maka sekolah tidak perlu lagi melakukan pengumuman atau membuka lowongan pekerjaan kedepan muka umum. Sekolah hanya perlu membuka berkas calon pelamar yang sebelumnya telah memberikan berkas lamarannya.

Stakeholder sekolah memiliki tiga hierarki pekerjaan yaitu unit ketua, unit pendukung pelaksana, dan unit pelaksana. Masing-masing unit dibagi menjadi beberapa jabatan, yaitu jabatan kepala sekolah, dan satu atau beberapa wakil kepala sekolah untuk unit pengelola. Unit pendukung pelaksana terdiri dari jabatan di laboratorium, sumber media, kurikulum, dan tata usaha. Unit pelaksana terdiri dari jabatan wali kelas, guru, dan narasumber. Masing-masing jabatan ini terdiri dari pekerjaan-pekerjaan yang dilakukan oleh setiap individu pada jabatan tata usaha misalnya bisa dipecah menajadi ketua, tugas keuangan, tugas kearsipan, dan tugas pembantu (Pidarta 2011).

Berdasarkan observasi diperoleh informasi bahwa dalam pengambilan keputusan penerimaan calon tenaga pendidik ialah stakeholder yang diantaranya ialah pihak yayasan, kepala sekolah atau wakil kepala sekolah. Penilaian dilakukan selama 3 bulan lamanya, panitia rekrutmen terdiri dari kepala sekolah. Panitia rekrutmen kemudian mengajukan namanama atau kandidat guru baru tersebut kepada yayasan. Sehingga yayasanlah yang menentukan diterima atau tidaknya calon guru baru tersebut. Kepala sekolah dan yayasan memegang peranan penting terhadap pengambilan keputusan diterimanya guru baru tersebut, yang berguna untuk keberlangsungan mutu pendidikan di SD Pertiwi. Karena tidak dapat dipungkiri bahwa salah satu penunjang agar mutu pendidikan dapat meningkat ialah pemilihan SDM di sekolah yang bisa disebut guru baru itu dengan prosedur yang benar dan tepat. 
SD Pertiwi sangat taat pada setiap peraturan dan prosedur yang mengatasnamakan pendidikan. Karena menurut SD Pertiwi baiknya kualitas tenaga pendidik itu dilihat dari berbagai segi. Misalnya disiplin kerja dan disiplin mengajar. Sehingga dapat menghasilkan outcome berupa guru yang berprestasi maupun guru yang memiliki kualitas pendidik yang baik. Sekolah bisa disebut efektif apabila outcome dari kegiatan organisasi sekolah memenuhi atau melebihi tujuan organisasi. Pada dasarnya hal tersebut sebenarnya bisa didapatkan dari prosedur atau tahap awal semenjak masa perekrutan tenaga pendidik. Dengan diberlakukannya prosedur yang sesuai maka sekolah akan mendapatkan tenaga pendidik yang sesuai dengan standar untuk memehuhi kebutuhan mengajar sekolah. Selain itu juga prosedur tersebut berkaitan dengan penentuan kebutuhan tenaga kerja di masa depan, baik dalam arti jumlah dan kualifikasi untuk mengisi berbagai jabatan dan menyelenggarakan berbagai aktivitas baru kelak.

Berdasarkan dari hasil temuan didapatkan selama proses pengambilan data dan wawancara maka ditemukan informasi bahwa tidak ada waktu atau tanggal khusus dalam kegiatan rekrutmen, karena kegiatan tersebut dibuka sesuai dengan kebutuhan saja atau bisa disebut kondisional. Lalu untuk rekrutmen, prosedur atau tahap awal dari proses rekrutmen ialah seleksi pada tahap lamaran, lalu tahap yang kedua adalah tes. Tes yang dilakukan berupa tes tertulis dan non-tertulis. Tes tertulis berupa penulisan RPP lalu untuk non-tertulis nya adalah tes microteaching (Mengajar). Selanjutnya adalah tahap orientasi. Tahap orientasi adalah tahap pengenalan untuk guru baru agar dapat menyesuaikan dengan lingkungan sekolah. Selanjutnya yang menentukan diterimanya calon tenaga pendidik yang telah lolos tahap rekrutmen ialah kepala sekolah dan yayasan.

Rekrutmen dan perkembangan karier itu saling berkesinambungan, dimana personel yang baru direkrut mempunyai kemampuan dan keahlian yang tepat sesuai dengan kebutuhan organisasi, hal tersebut juga terjadi bila ada perubahan teknologi yang diterapkan oleh organisasi dengan ketersediaan kemampuan dan keahlian personel yang ada. Jadi perkembangan karier diperlukan bukan hanya untuk personel baru saja, tetapi juga untuk personel yang lama sepanjang adanya kesenjangan antara kemampuan atau keahlian yang dimiliki oleh personel yang bersangkutan dengan kebutuhan organisasi.

Perkembangan karier untuk tenaga pendidik berguna untuk meningkatkan kinerja karyawan melalui peningkatan kemampuan dan pengetahuannya dengan mengikuti pelatihan atau pendidikan. Kegiatan tersebut dapat dilakukan di dalam sekolah ataupun di luar sekolah, tergantung pertimbangan efektivitas dan efisiensinya. Program pengembangan karier untuk guru dianggap sangat penting untuk keberlangsungan pendidikan di SD Pertiwi. Maka dari itu, SD Pertiwi menganggap perkembangan karier itu sangat penting. Karena perkembangan karier guru sangat menunjang kompetensi guru. Tenaga pendidik di SD Pertiwi menganggap bahwa program perkembangan karier sangat penting. Selain untuk meningkatkan mutu lulusan, tenaga pendidik pun jadi open minded atau luas wawasannya. Tak salah jika kepala sekolah membuat program perkmbangan karier yang diperuntukan untuk tenaga pendidik di SD Pertiwi. Kepala sekolah akhirnya membuat program perkembangan karier yang sesuai untuk tenaga pendidik di SD Pertiwi. Sesuai 
dengan teori mengenai perkembangan karier guru ialah mengenai pembinaan dan pengembangan profesi dan karier guru.

Pembinaan dan pengembangan profesi dan karier guru, termasuk juga tenaga kependidikan pada umumnya, dilaksanakan melalui berbagai strategi dalam bentuk diklat (pendidikan dan pelatihan) maupun bukan diklat,antara lain ialah: 1) Pendidikan dan pelatihan diantaranya adalah program IHT (In-house training) yang berupa pelatihan yang dilaksanakan secara internal di kelompok kerja guru, pendidikan lanjut yaitu pembinaan profesi guru melalui pendidikan lanjut juga merupakan alternatif bagi peningkatan kualifikasi dan kompetensi guru, pembinaan internal oleh sekolah yaitu pembinaan yang dilaksanakan oleh kepala sekolah; 2) Kegiatan selain pendidikan dan pelatihan diantaranya adalah seminar. Seminar merupakan kegiatan pembinaan publikasi ilmiah yang juga dapat menjadi model pembinaan berkelanjutan bagi peningkatan keprofesian guru. Kemudian ada workshop, yang dilakukan untuk menghasilkan produk yang bermanfaat bagi pembelajaran, peningkatan kompetensi, maupun pengembangan karir. Pembuatan media pembelajaran, media pembelajaran yang dibuat dapat berbentuk alat peraga, alat praktikum sederhana, maupun bahan ajar elektronik atau animasi pembelajaran (Sudarwan 2012).

Sesuai dengan teori, jenis perkembangan karier guru itu ada 2, yaitu pendidikan dan pelatihan, serta kegiatan pendidikan dan pelatihan. Diperoleh informasi bahwa di SD Pertiwi rutin melaksanakan program perkembangan karier guru. Baik itu melalui pendidikan dan pelatihan ataupun kegiatan yang bukan pendidikan dan pelatihan. Salah satu program unggulan dari program perkembangan karier di SD Pertiwi ialah dalam pendidikan pelatihan. Di dalam pendidikan dan pelatihan ada pendidikan tindak lanjut. Dimana pendidikan tindak lanjut adalah pelaksanaan pendidikan di tingkat yang lebih tinggi yang berguna untuk membantu guru dalam mengembangkan potensinya. Pendidikan tindak lanjut ini dapat berupa melanjutkan jenjang pendidikan yang lebih tinggi. Seperti yang ditemukan dari hasil wawancara dan dokumentasi bahwa program unggulan dari perkembangan karier di SD Pertiwi ialah dengan diadakannya program beasiswa untuk tenaga pendidik sebagai reward ataupun motivasi untuk menunjang kinerja guru agar lebih baik lagi. Beasiswa tersebut berupa financial atau biaya administrasi yang ditanggung oleh yayasan untuk tenaga pendidik yang ingin melanjutkan pendidikan ke jenjang yang lebih tinggi. Beasiswa tersebut diberikan untuk jenjang S1 dan S2. Dengan adanya program karier seperti itu maka setiap tenaga pendidik tidak akan menyia-nyiakan kesempatannya untuk dapat meningkatan kompetensinya sebagai guru. Peluang yang telah diberikan oleh sekolah sangat bermanfaat bagi keberlangsungan pendidikan. Sehingga mutu pendidikan dapat terus meningkat.

Program beasiswa disebut-sebut sebagai program unggulan di SD Pertiwi. Program tersebut sangat menguntungkan bagi kedua belah pihak. Baik untuk sekolah maupun untuk pribadi tenaga pendidik. Beasiswa yang diberikan oleh yayasan untuk subsidi beasiswa mencapai 2 tingkat. Yaitu tingkat S1 dan S2. Sangat disayangkan apabila tenaga pendidik menyia-nyiakan kesempatan tersebut. Program unggulan lain yang ditemukan dalam perkembangan karier di SD Pertiwi ialah program pertemuan diskusi masalah-masalah tentang dunia pendidikan. Khususnya dalam proses mengajar, program tersebut berjalan 1 minggu sekali. Peserta dari program 
tersebut tak lain ialah tenaga pendidik di sekolah. Setiap tenaga pendidik di tingkatan kelas, pasti akan melakukan pertemuan untuk membahas permasalahan yang ditemukan ketika dalam kegiatan pembelajaran. Pertemuan tersebut akan dibuatkan jadwalnya sesuai dengan kebutuhan.

Pentingnya program perkembangan bagi sekolah itu karena tiap sekolah akan menampilkan gambarannya masing-masing sesuai dengan kinerja organisasi yang tercapai. Untuk itu kualitas kinerja sekolah akan memberikan gambaran tentang tingkat efektivitas dari sekolah, sehingga kategori efektif menjadi salah satu hal yang penting untuk melihat pencapainnya sekolah dalam konteks pencapaian tujuan pendidikan. Salah satu penunjang untuk menyelaraskan tujuan tersebut ialah diadakannya program perkembangan karier. Program Perkembangan karier guru di SD Pertiwi sudah berjalan dengan efektif. Pernyataan tersebut dapat dibuktikan dari hasil wawancara yang telah dilakukan. Kesiapan dan keseriusan sekolah dalam membuat program perkembangan karir nampaknya membuat program tersebut tidak menemukan suatu kendala. Sehingga tenaga pendidik dapat melaksanakan tugas dan kewajibannya dengan baik dan lancar. Dengan demikian, pelaksanaan program perkembangan karier di SD Pertiwi telah terlaksana dengan baik dan tanpa kendala. Kepala sekolah dan tenaga pendidik bekerja sama dalam melakukan program tersebut sehingga tidak ditemukannya suatu kendala dan masing-masing pihak tidak ada yang merasa dirugikan.

Reward bisa didapatkan apabila seseorang telah melewati berbagai macam usaha. Salah satunya ialah dengan melaksanakan program perkembangan karier, sehingga manfaat yang dirasakan oleh seorang tenaga pendidik ialah meningkatnya kinerja dan juga mutu pendidikan. Sekolah memberikan sebuah reward atau penghargaan bagi tenaga pendidik yang telah melaksanakan tugasnya dengan baik. Reward yang telah diberikan memang sudah selayaknya diterima oleh tenaga pendidik yang telah berjuang dan berusaha dalam mengembangkan diri sehinnga kinerja dari tenaga pendidik pun meningkat. Reward seperti itu jarang ditemui di sekolah lainnya. Terkecuali jika memang sudah menjadi program tetap yang diberikan oleh pemerintah. Tak ada salahnya memberikan suatu penghargaan untuk seorang tenaga pendidik yang telah berusaha keras mengejar apa yang menjadi tujuan utama suatu organisasinya. Justru dengan diadakannya reward seperti itu, tenaga pendidik menjadi semakin termotivasi untuk menjalankan kewajibannya.

\section{KESIMPULAN DAN IMPLIKASI}

\section{Kesimpulan}

Rekrutmen tenaga pendidik di SD Pertiwi kota Bogor dilakukan melalui disiplin kerja dan disiplin mengajar. Sehingga dapat menghasilkan outcome berupa guru yang berprestasi maupun guru yang memiliki kualitas pendidik yang baik. Prosedur atau tahap awal dari proses rekrutmen ialah seleksi pada tahap lamaran, lalu tahap yang kedua adalah tes. Tes yang dilakukan berupa tes tertulis dan non-tertulis. Tes tertulis berupa penulisan RPP lalu untuk non-tertulis nya adalah tes microteaching (Mengajar). Selanjutnya adalah tahap orientasi. Tahap orientasi adalah tahap pengenalan untuk guru baru agar dapat menyesuaikan dengan lingkungan sekolah. Selanjutnya yang menentukan diterimanya calon tenaga pendidik yang telah lolos tahap 
rekrutmen ialah kepala sekolah dan yayasan.

\section{Implikasi}

Perkembangan karier untuk tenaga pendidik berguna untuk meningkatkan kinerja karyawan melalui peningkatan kemampuan dan pengetahuannya dengan mengikuti pelatihan atau pendidikan. Kegiatan tersebut dapat dilakukan di dalam sekolah ataupun di luar sekolah, tergantung pertimbangan efektivitas dan efisiensinya, diantaranya ialah program pendidikan dan pelatihan, serta kegiatan bukan pendidikan dan pelatihan. Untuk program pendidikan dan pelatihan, SD Pertiwi memiliki program unggulan berupa program beasiswa, dan untuk kegiatan bukan pendidikan dan pelatihan SD Pertiwi memiliki program pertemuan setiap minggunya untuk berdiskusi seputar masalah-masalah pendidikan. Sampai saat ini program tersebut berjalan dengan baik dan lancar tanpa adanya kendalan dan berjalan dengan efektif.

\section{DAFTAR PUSTAKA}

Harsono. 2011. Sistem administrasi kepegawaian. Kusmedia, Bandung.

Heryati Y dan M Muhsin. 2014. Manajemen sumber daya pendidikan. Pustaka Setia, Bandung.

Kuncoro MW. 2017. Evaluasi kualitas tes psikologi kepribadian. Jurnal Sosio Humaniora 3(2).

Miles MB dan AM Huberman. 1992. Analisis data kualitatif: buku sumber tentang metode-metode baru. UI Press, Jakarta.

Moleong LJ. 2007. Metodologi penelitian kualitatif. Remaja Roesdakarya, Bandung.

Mustari M. 2014. Manajemen pendidikan. Raja Grafindo, Jakarta.
Pidarta M. 2011. Manajemen pendidikan Indonesia. Asdi Mahasatya, Jakarta.

Prihatin E. 2011. Teori administrasi pendidikan. Alfabeta, Bandung.

Republik Indonesia. 2003. Undang-undang Nomor 20 Tahun 2003 tentang Sistem Penddikan Nasional. Sekretariat Negara. Jakarta.

Republik Indonesia. 2015. Laporan Akuntabilitas Kinerja Instansi Pemerntah Kemendikbud Tahun 2015 tentang Kinerja Guru. Sekretarian Negara. Jakarta. Rugayah. 2010. Profesi kependidikan dalam perspektif pendidikan. Alfabeta, Bandung.

Setiani B. 2013. Kajian sumber daya manusia dalam proses rekrutmen tenaga kerja di perusahaan. Skripsi. Universitas Suryadarma, Jakarta.

Siagian SP. 2008. Manajemen sumber daya manusia. Bumi Aksara, Jakarta.

Sudarwan D. 2012. Profesi kependidikan. Alfabeta, Bandung.

Sugiono. 2014. Memahami penelitian kualitatif. Alfabeta, Bandung.

Sukinah. 2016. Meningkatkan aktivitas dan hasil belajar siswa kelas VIII-D SMP Negeri 33 Surabaya dalam pelajaran matematika melalui media berbantuan komputer. Jurnal Dinas Pendidikan Kota Surabaya. Volume 3.

Sutrisno E. 2009. Manajemen sumber daya manusia. Kencana, Jakarta.

Sutrisno E. 2014. Manajemen sumber daya manusia. Prenada Media Grup, Jakarta.

Tim Dosen Administrasi Pendidikan Universitas Pendidikan Indonesia. 2012. Manajemen pendidikan. Alfabeta, Bandung.

Yin RJ. 2004. Studi kasus desain dan metode. Raja Grafindo Perkasa, Jakarta. 